\title{
PENGUATAN MANAJEMEN SYARIAH MELALUI TOTAL QUALITY MANAGEMENTBAGI PELAKU LEMBAGA KEUANGAN SYARIAH DI KOTA SEMARANG
}

\author{
Johan Arifin \\ Fakultas Ekonomi dan Bisnis Islam Universitas Islam Negeri Walisongo \\ Semarang \\ Email:johanarifin71@gmail.com
}

\begin{abstract}
One of the problems that arise in the Islamic financial management is the governance model (management) used are the same as a conventional financial institution management in general, Therefore we need innovation in management. Management Implementation of Sharia in the Islamic financial institutions are expected to improve the performance and quality of these institutions. Implementation of sharia management really comes down to the issue of Total Quality Management (TQM) on financial institutions syar'iab focused on the process of continuous improvement to uphold the values of Shariah.

Management of sharia is considered important in the company since its implementation in the areas of services and operating in personal competence, maintaining the availability of knowledge and innovation as well as product development. Through sharia management is expected to increase the skills and motivation to work on giliranyy a will improve the reinforcement of the operational side. The perpetrator of Islamic financial institutions in terms of technical skills are adequate but the problem is the knowledge of the management of sharia. Knowledge management in Islamic financial institutions will be judged by the public that the management is not different from the conventional financial institutions.
\end{abstract}

Keywords: Management of sharia, LKS, TQM

\begin{abstract}
Abstrak
Salah satu masalah yang timbul dalam pengelolaan keuangan Islam adalah model tata kelola (manajemen) yang digunakan adalah sama sebagai manajemen lembaga keuangan konvensional pada umumnya, karena itu kita perlu inovasi dalam manajemen. Implementasi manajemen Syariah di lembaga keuangan syariah diharapkan untuk meningkatkan kinerja dan kualitas Ulasan institutions. Implementation ini manajemen syariah benarbenar turun ke isu Total Quality Management (TQM) pada lembaga
\end{abstract}


keuangan syari'ah difokuskan pada proses perbaikan terus-menerus untuk menegakkan nilai-nilai Syariah.

Manajemen syariah dianggap penting dalam perusahaan sejak pelaksanaannya di bidang jasa dan beroperasi di kompetensi personal, menjaga ketersediaan pengetahuan dan inovasi serta manajemen produk syariah development. Through diharapkan dapat meningkatkan keterampilan dan motivasi kerja pada giliranya akan meningkatkan penguatan sisi operasional. Pelaku lembaga keuangan syariah dalam hal keterampilan teknis yang memadai tapi masalahnya adalah pengetahuan tentang manajemen syariah. Manajemen pengetahuan di lembaga keuangan Islam akan dinilai oleh masyarakat bahwa manajemen tidak berbeda dari keuangan institutions.

Kata Kunci: Manajemen syariah, LKS, TQM

\section{A. Latar Belakang}

Berdasarkan data statistik perbankan syariah jumlah Bank Syariah per Januari 2016 telah mencapai 34 unit yang terdiri atas 12 Bank Umum Syariah (BUS) dan 22 Unit Usaha Syariah (UUS). Selain itu, jumlah Bank Pembiayaan Rakyat Syariah (BPRS) telah mencapai 148 unit pada periode yang sama. Pada bulan Januari 2016 jumlah telah terdapat sebesar 693 Kantor Pusat Operasional/Kantor Cabang (138 Kantor Cabang BUS dan 103 Kantor Cabang UUS), 1.449 Kantor Cabang Pembantu/Unit Pelayanan Syariah, dan 427 Kantor Kas. Di provinsi Jawa Tengah sendiri, pada bulan Januari 2016 telah terdapat 40 Kantor Pusat Operasional/Kantor Cabang BUS, 108 Kantor Cabang Pembantu/Unit Pelayanan Syariah BUS, dan 21 Kantor Kas BUS. Sementara untuk kantor cabang UUS sebanyak 17 kantor, kantor cabang pembantu UUS sebanyak 7, dan kantor kas UUS sebesar 6 kantor. Sementara itu, jumlah BPRS di Jawa Tengah sebesar 26 bank (Otoritas Jasa Keuangan, 2016).

Industri perbankan syariah semakin menghadapi banyak tantangan akibat bergabungnya sejumlah institusi, kolaborasi inter-organisasi, pengembangan berbagai produk dan jasa, serta perbaikan mutu. Untuk merespon dengan efektif berbagai tantangan ini, penciptaan sistem yang memenuhi level "quality" yang sesuai dengan konsep syariah menjadi isu vital nyata yang menantang (Musari, 2010). Selain itu, untuk memperoleh keunggulan daya saing dalam skala global, suatu perusahaan dituntut harus mampu menyajikan setiap proses yang lebih baik dalam rangka 
menghasilkan barang atau jasa yang mempunyai kualitas tinggi dengan harga yang wajar dan mampu bersaing.

Oleh karena itu, untuk mengoptimalkan fungsi dan perannya, revitalisasi manajerial Lembaga Keuangan Syariah (LKS) ke arah yang lebih baik sangat diperlukan. Lembaga Keuangan Syariah harus memenuhi standar manajemen mutu agar mendapat kepercayaan besar dari publik. Lebih dari itu, kinerja mutu Lembaga Keuangan Syariah perlu mendapat perhatian agar tujuan dari keberadaan lembaga itu dapat tercapai. Standar mutu merupakan sesuatu yang penting bagi sebuah organisasi termasuk Lembaga Keuangan Syariah walaupun pada mulanya istilah mutu digunakan oleh perusahaan sebagai upaya meningkatkan kualitas produk agar memberikan kepuasan bagi konsumen. TQM didasarkan pada partisipasi semua anggota organisasi dalam meningkatkan proses, produk, jasa, dan budaya dimana mereka bekerja di dalamnya. TQM memberikan keuntungan bagi semua anggota organisasi dan masyarakat (Sugian, 2006). Keuntungan tersebut diperoleh berkat kerjasama semua komponen dalam perusahaan serta adanya komitmen menghasilkan produk yang berkualitas.

Di Indonesia konsep TQM pertama kali diperkenalkan pada tahun 1980-an dan saat ini sudah cukup populer terutama di sektor swasta antara lain dengan adanya program ISO 9000 (Tunggal, 1993). Sampai saat ini ISO-9000 telah diterapkan oleh 53 negara termasuk MEE dan negaranegara di Asia Selatan/Timur seperti Singapura, Malaysia, Hongkong, dan Cina. Pemerintah Indonesia pun menerapkan standar ISO 9000 dimana dalam PP No. 15/1991 tentang Standar Nasional Indonesia (SNI) dan Keppres No 12/1991 tentang penyusunan, penerapan dan pengawasan SNI, juga mengarah pada persyaratan yang diterapkan oleh standar ISO 9000. Dengan adanya standar nasional, pemerintah menginginkan perusahaan-perusahaan di Indonesia dapat bersaing di dunia internasional dengan produk-produk yang berkualitas sesuai standar internasional.

Lembaga Keuangan Syariah harus berpegang pada prinsip syariah dan memberikan dampak perubahan bagi kesejahteraan masyarakat didukung oleh kepercayaan yang tinggi dari masyarakat. Dengan kepercayaan tersebut bagaimanakah LKS memberikan pelayanan terbaik sehingga memberikan kepuasan bagi para nasabahnya. Permasalahan yang dibahas dalam penelitian ini adalah mengenai pelaku lembaga keuangan syariah khususnya di Baitul Maal wa Tamwil (BMT) terhadap implementasi manajemen syariah. Masalah ini menarik seiring perkembangan lembaga keuangan syariah yang tumbuh pesat. 
Perkembangan lembaga keuangan syariah di Indonesia cukup pesat, meskipun market share-nya masih relatif kecil bila dibanding dengan keuangan konvensional.

Salah satu persoalan yang muncul dalam pengelolaan keuangan syari'ah adalah model tata kelola (manajemen) yang digunakan masih sama dengan manajemen lembaga keuangan konvensional pada umumnya. Oleh karena itu diperlukan inovasi dalam pengelolaannya. Implementasi Manajemen syariah pada lembaga keuangan syariah diharapkan mampu meningkatkan kinerja dan kualitas lembaga tersebut. Implementasi manajemen syariah sebenarnya bermuara pada persoalan Total Quality Management (TQM) pada lembaga keuangan syari'ah dengan dititikberatkan pada proses perbaikan terus-menerus dengan memegang teguh nilai-nilai syari'ah.

Permasalahan yang terjadi di lembaga keuangan syariah secara umum berkaitan dengan resiko pembiayaan dan resiko operasional. Resiko operasional berkaitan dengan core banking system dan kompetensi Sumber Daya Manusia (SDM). Manajemen syariah merupakan sebuah alat meningkatkan kinerja SDM dan perusahaan melalui pengelolaan aset pengetahuan dalam perusahaan. Manajemen syariah ini dipandang penting dalam perusahaan karena implementasinya pada bidang pelayanan dan operasi dalam kompetensi personal, memelihara ketersediaan knowledge dan inovasi serta pengembangan produk. Melalui manajemen syariah ini diharapkan akan meningkatkan keahlian dan motivasi kerja yang pada gilirannya akan meningkatkan penguatan dari sisi operasional.

Inti penelitian ini mengenai penguatan pelaku lembaga keuangan syariah terhadap aspek-aspek manajemen syariah. Aspek tersebut diduga sebagai kekuatan strategis yang perlu dibina dan dikembangkan untuk meningkatkan daya saing. Berdasarkan latar belakang di atas, maka pertanyaan besar dalam penelitian ini adalah, bagaimanakah implementasi nilai-nilai TQM pada manajemen lembaga keuangan syariah saat ini. Indikator manajemen mutu meliputi banyak hal yaitu: kepemimpinan, perencanaan strategis, pengelolaan manajemen, pengukuran, analisis dan pengetahuan manajemen pengetahuan, sumber daya manusia, dan pencapaian hasil. 


\section{Manajemen Syariah Melalui Total Quality Management (TQM)}

\subsection{Eksistensi Manajemen Syariah}

\subsubsection{Manajemen Syariah}

Perkembangan manajemen baik sebagai ilmu maupun seni mulai tampak diterapkan seiring munculnya industri pada abad ke 19. Manajemen lahir sebagai tuntutan perlunya pengaturan individu dalam organisasi. Adanya fungsi dan tanggungjawab antara terhadap anggota organisasi dalam bentuk mengatur dan memberikan pelayanan dan menjalankan operasi organisasi.

Manajemen syariah secara terminologi didefinisikan sebagai manejemen yang dilandasi hukum-hukum Islam yang bersumber al Quran dan Hadis. Manajemen syariah lahir untuk menyelesaikan carut marutnya dunia bisnis yang tidak bisa diakomodir, Oleh karena itu manajemen syariah manajemen yang tidak bebas nilai. ${ }^{1}$

Islam sebagai suatu sistem nilai yang hidup dan memiliki konsep pemikiran tentang manajemen. Menurut Didin dan Hendrin dalam bukunya "Manajemen syariah dalam praktek" mengatakan bahwa manajemen dikatakan telah memenuhi apsek-aspek kesyariahan bila: manajemen yang dilaksanakan memenuhi perilaku yang terkait dengan nilai-nilai keimanan dan ketauhidan. Kedua, Manajemen syariah juga mementingkan struktur organisasi. Ini bisa dilihat bahwa peranan dan kemampuan manusia tidak akan sama, Manajemen syariah membahas soal sistem. Sistem ini ini dibuat agar pelaku didalamnya berjalan secara teratur dan mengikuti layanan lembaga keuangan yang berbasis syariah. Sistem ini berkaitan erat dengan perencanaan, organisasi dan kontrol. ${ }^{2}$

Menurut Karebet dan Yusanto, Syariah memandang manajemen dari dua sisi, yaitu manajemen sebagai ilmu dan manjemen sebagai aktifitas. Sebagai ilmu, manajemen dipandang sebagai salah satu dari lmu umum yang lahir berdasarkan fakta empiris tidak berkaitan dengan nilai, peradaban (hadlarah) manapun. Namun sebagai aktifitas, maka manajemen dipandang sebagai sebuah amal yang kelak akan dimintai

\footnotetext{
${ }_{1}$ Didin hafifuddin dan Hendri Tanjung, 2003, Manajemen Syariah Dalam Praktek, Gema Insani, Jakarta, Hal. 5

2 Kuat Susanto, 2009, Manajemen Syariab: Implementasi TQM dalam Lembaga Kenangan Syariah, Pustaka Pelajar, yogyakarta hal.13
} 
pertanggungjawabannya di hadapan Allah SW'T, sehingga ia harus terikat dengan peraturan syara', nilai dan peradaban islam. ${ }^{3}$

Indentitas lembaga keuangan yang berbasis syariah sebagai institusi yang mempunyai karakter berbeda karena ada nilai-nilai kesyariahan yang harus menjadi budaya organisasi yang tercermin dalam tata kelola manajemen syariah dan identitas ini merupakan ciri khas diri lembaga keuangan yang lainnya. Lembaga keuangan syari'ah memiliki otoritas untuk mengembangkan dan merencanakan tata kelola manajemen yang berbasis syariah utamanya adalah para pelakunya. Semua ini merupakan aset dari sebuah organisasi paling penting yang harus dimiliki oleh sebuah lembaga dan harus diperhatikan oleh manajemen. Manusia, kata Henry Simamora, "merupakan elemen yang selalu ada di dalam setiap organisasi. Mereka membuat tujuan, inovasi, dan mencapai tujuan organisasi. Orangorang tersebut merupakan sumber daya manusia, dan sebagai sumber daya yang paling penting ${ }^{5}$ bagi organisasi”.

\subsection{Total Quality Management}

Secara bahasa, TQM terdiri dari tiga unsur, yaitu total, quality, dan management. Kata "total" dalam konsep TQM diartikan sebagai pengintegrasian seluruh staf, penyalur, pelanggan dan stakeholder lainnya (total is the integration of the staff, suppliers, customers and other stakeholders) ${ }^{6} \mathrm{Hal}$ ini berarti semua orang yang ada di dalam organisasi dilibatkan dalam menyelesaikan produk atau melayani pelanggan. Dengan kata lain, "total" dalam konsep TQM ini diartikan bahwa setiap orang berperan dalam menyukseskan seluruh proses pekerjaan atau aktivitas ${ }^{7}$

Unsur yang kedua dari TQM adalah "Quality". Quality ini memiliki banyak definisi, baik yang konvensional maupun yang strategik. Secara konvensional, quality biasanya menggambarkan karakteristik langsung dari suatu produk, seperti kinerja (performance), keandalan (reliability), mudah dalam penggunaan (easy of use), estetika (esthetics), dan sebagainya. Definisi lain dari quality yang lebih strategik adalah segala sesuatu yang mampu

\footnotetext{
3 Yusanto dan Karebet, 2007, Menggagas Bisnis Islam, Gema Isnsani Jakarta, Hal. 31 lihat juga Mathis, R.L. \& J.H. Jackson. 2006. Human Resource Management: Manajemen Sumber Daya Manusia. Terjemahan Dian Angelia. Jakarta: Salemba Empat.

${ }^{4}$ Henry Simamora, Manajemen Sumber daya Manusia, Yogyakarta: STIE YKPN, 1995, h: 1

${ }^{5}$ Ibid.

6 Ardiani, "Information Resources Guide on Total Quality Management" dalam http://edu-articles.com/?pilih=lihat\&id $=55$

7 Oliver, Paul (Ed.)1996,,The Management of Educational Change; a Case-Study Approach, England: Arena, hal, 67
} 
memenuhi keinginan atau kebutuhan pelanggan (meeting the needs of

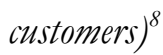

Secara operasional, mutu/kualitas ditentukan oleh dua faktor, yaitu terpenuhinya spesifikasi yang telah ditentukan sebelumnya dan terpenuhinya spesifikasi yang diharapkan menurut tuntutan dan kebutuhan pelanggan. Mutu yang pertama disebut quality in fact (mutu sesungguhnya) dan yang kedua disebut quality in perception (mutu persepsi)

Dalam quality in fact, para produsen menunjukkan bahwa mutu memiliki sebuah sistem, yang biasa disebut sistem jaminan mutu (quality assurance system), yang memungkinkan roda produksi menghasilkan produkproduk yang secara konsisten sesuai dengan standard atau spesifikasi tertentu. Dengan demikian sebuah produk dikatakan bermutu selama produk tersebut secara konsisten sesuai dengan tuntutan pembuatnya.

Adapun dalam quality in perception, mutu didefinisikan sebagai sesuatu yang memuaskan atau melampaui keinginan dan kebutuhan pelanggan. Dalam hal ini yang menentukan atau menilai sebuah produk atau jasa bermutu ataupun tidak adalah para pelanggan. Dengan demikian mutu dalam persepsi diukur dari kepuasan pelanggan atau pengguna serta meningkatnya minat pelanggan terhadap produk atau jasa.

Unsur yang terakhir adalah management yang berarti sistem mengelola dengan menggunakan langkah-langkah seperti merencanakan, mengorganisir, mengendalikan, memimpin, dan lain-lain. ${ }^{9}$ Pengertian yang lain menyebutkan manajemen sebagai proses perencanaan, pengorganisasian, penggerakan dan pengontrolan sumber daya manusia dan sumber daya yang lain guna mencapai tujuan secara efektif dan efisien. ${ }^{10}$ Namun begitu, ada perbedaan antara manajemen konvensional dengan manajemen dalam konsep TQM. Kalau dalam manajemen konvensional yang dikelola adalah $7 \mathrm{M}$, yakni man, money, materials, methods, machine, markets, minute, maka dalam konsep TQM yang di manajemen adalah quality atau mutu dari barang dan/atau jasa yang dihasilkan. ${ }^{11}$ Selain

\footnotetext{
${ }^{8}$ Gaspersz, Vincent, 2001, Total Quality Management, Jakarta: Gramedia Pustaka Utama, hal 20

9 Benny, "Keuntungan Menerapkan Total Quality Management (TQM) DI UKM/IKM" dalam http://www.bsn.or.id/NEWS/detail_news.cfm?News_id=15

10 Poerwowidagdo, Sapto. J., "Upaya Implementasi Total Quality Leadership di TNIAngkatan Laut”, dalam http://www.hangtuah.ac.id/Sapto/total-quali.htm

${ }^{11}$ Ardiani, "Pengertian Manajemen Mutu Terpadu" dalam http://eduarticles.com/?pilih=lihat \&id $=45$
} 
itu, yang perlu juga dipahami bahwa kata "manajemen" dalam konsep TQM ini berlaku untuk setiap orang yang berada dalam organisasi.

Dari definisi-definisi tersebut di atas, kiranya Total Quality Management atau Manajemen Mutu Terpadu dapat didefinisikan sebagai suatu sistem manajemen yang melibatkan semua unsur kepegawaian di lingkungan suatu perusahaan baik sektor barang (good product) maupun sektor jasa (services) yang bertujuan untuk meningkatkan mutu, efisiensi dan efektivitas produksi baik di lingkungan industri maupun institusi lainnya. ${ }^{12}$

Dengan beberapa pengertian tersebut di atas, maka dapat dikatakan bahwa TQM adalah sebuah pendekatan praktis namun juga strategis dalam menjalankan roda organisasi yang memfokuskan diri pada terpenuhinya ekspektasi pelanggan dan klien dengan melakukan perbaikan terus menerus serta melibatkan seluruh sumber daya yang ada secara efektif dan efisien.

\subsubsection{Konsep Manajemen Kualitas (Quality Management)}

Istilah kata "kualitas" (quality) atau mutu diterapkan pada berbagai keadaan baik barang (benda) yang kongkrit maupun abstrak (Stoner \& Freeman, 1995). Penilaian terhadap quality berbeda antara satu objek dengan objek lainnya. Misal, menilai quality pendidikan tentu akan berbeda dengan menilai produksi pabrik atau menilai sebuah jasa (Sallis, 2002). Dengan demikian, konsep quality akan berbeda dalam waktu dan tempat berlainan sesuai dengan perubahan kehidupan manusia dari masa lampau sampai modern.

Dalam pandangan tradisional quality sebagai isu teknis dalam produksi. Aktivitas inspeksi terhadap produk dilakukan setelah selesai dibuat, yang dilakukan untuk mencegah jatuhnya produk ke tangan konsumen. Hal ini berbeda dengan konsep kualitas dalam pandangan modern yang menjadikan kualitas sebagai isu bisnis. Konsep kualitas tidak sekedar aktivitas inspeksi melainkan mencakup semua fungsi atau manajemen dalam organisasi (Gaspersz, 2008). Dalam pandangan modern dikenal adanya komponen-komponen yang berhubungan dengan produk seperti: performance, reliability, ease to use, aesthetics (Bartol \& Martin, 1998). Ada pula hal lain seperti kecepatan dan kompetensi saat produk direparasi

${ }^{12}$ Hendayana, Rachmat, "Implementasi Gugus Kendali Mutu dalam Kegiatan Pengkajian” dalam http://bp2tp.litbang.deptan.go.id/file/wp04_15_gkm.pdf. 
(serviceability) dan kemampuan perawatan (maintainability) (Feigenbaum, 1991).

ISO 8402 (Quality Vocabulary) mendefinisikan kualitas sebagai totalitas dari karakteristik suatu produk yang menunjang kemampuannya untuk memuaskan kebutuhan yang dispesifikasikan atau ditetapkan (Gaspersz, 2008). Pendapat lain menyebutkan kualitas sebagai segala sesuatu yang menentukan kepuasan pelanggan dan upaya perubahan ke arah perbaikan secara terus-menerus. Dalam hal ini dikenal istilah QMATCH (Quality = Meets, Agreed, Terms, and Changes) (Gaspersz, 2008). Pada perusahaan jasa yang lebih menekankan pada service (pelayanan) secara langsung, tentu quality terletak pada kinerja para pegawai dalam memberikan pelayanan kepada pelanggan.

Terdapat perbedaan antara persepsi atau penilaian seseorang dengan yang lainnya dalam hal suatu barang/produk, hal itu terkait pula dengan penilaian antara quality produk dan quality jasa. Mutu jasa (service quality) terkait dengan perilaku atau sifat para pekerja/pegawai yang memberikan pelayanan. Karena, pelayan merupakan kunci utama yang memberikan baik buruknya sebuah industri jasa. Dalam perusahaan atau lembaga yang terfokus pada pelayanan, professionalisme pegawai sangat menunjang tingkat kepuasan dan kenyamanan pelanggan. Karena pegawai berhadapan langsung dengan pelanggan (konsumen).

Manajemen Kualitas (Quality Management) atau Manajemen Kualitas Terpadu (Total Quality Management) sebagai suatu cara meningkatkan performansi secara terus-menerus (continuous performance improvement) pada setiap level operasi atau proses, dalam setiap area fungsional dari suatu organisasi, dengan menggunakan semua sumber daya manusia disertai modal yang tersedia (Gaspersz, 2008) dalam upaya meningkatkan quality semua proses, produk, dan jasa dalam sebuah organisasi (Bartol \& Martin, 1998).

Total quality sebagai pendekatan yang berusaha untuk meningkatkan daya saing organisasi melalui peningkatan secara terus menerus dalam hal quality produk, pelayanan, sumber daya manusia, proses dan lingkungan (Goetsch \& Davis, 2010). Rumusan TQM tidak terlepas dari dua aspek yaitu customer (pelanggan) dan pemeliharaan.

Menurut Sashkin dan Kiser (1992) menyatakan bahwa quality control merupakan sebuah sistem untuk memproduksi barang-barang ekonomis yang ditujukan untuk memberikan kepuasan bagi pelanggan. Definisi quality control pada intinya tidak jauh berbeda dengan definisi TQM lainnya. 
Secara global bahwa TQM dilakukan agar perusahaan memperoleh keunggulan pada semua dimensi dari produk dan jasa, yang penting bagi pelanggan (Tunggal, 1993). Sementara dalam ISO 8402 (Quality Vocabulary) seperti yang dikutip oleh (Gaspersz, 2008) bahwa quality management adalah semua aktivitas dari fungsi manajemen secara keseluruhan yang menentukan kebijakan kualitas, tujuan-tujuan dan tanggung jawab serta mengimplementasikannya melalui alat-alat seperti perencanaan kualitas (quality planning), pengendalian kualitas (quality contro), jaminan kualitas (quality assurance) dan peningkatan kualitas (quality improvement).

TQM sendiri dapat diartikan sebagai pengelolaan kualitas semua komponen (stakeholder) yang berkepentingan dengan visi dan misi organisasi. Pada dasarnya TQM itu bukanlah pembebanan ataupun pemeriksaan, tetapi TQM adalah lebih dari usaha untuk melakukan sesuatu yang benar setiap waktu, dari pada melakukan pemeriksaan pada waktu tertentu ketika terjadi kesalahan. TQM merupakan perluasan dan pengembangan dari jaminan mutu. Total Quality Management adalah tentang usaha menciptakan sebuah kultur mutu, yang mendorong semua anggota stafnya untuk memuaskan para pelanggan. Kualitas dijelaskan juga di dalam Alquran, seperti dalam QS. As-Syua'ra ayat 181-182:

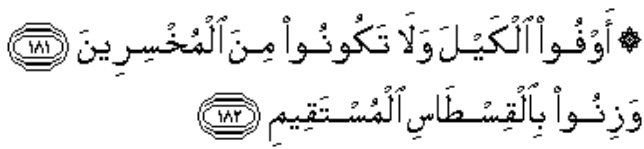

Artinya: "Sempurnakanlah takaran dan janganlah kamu termasuk orang-orang yang merugikan (181). Dan timbanglah dengan timbangan yang lurus (182).

Berdasarkan ISO 8402 tampak bahwa quality management dilakukan sejak awal produksi, saat proses serta akhir. Ini artinya manajemen kualitas terjadi secara berkesinambungan dan terus-menerus dalam seluruh proses produksi sehingga quality dapat terjamin dan terpelihara. Quality merupakan faktor yang harus diperhatikan oleh sebuah perusahaan dalam seluruh bagian serta seluruh proses produksi. Konsep quality yang ada dalam ISO 8402 itu memiliki prinsip penjaminan kualitas secara berkesinambungan dan menyeluruh pada semua level dan tahapan.

Konsep TQM muncul di Jepang pasca perang dunia II. Istilah tersebut dicetuskan oleh Naval Air Systems Command untuk mendeskripsikan pendekatan gaya-Jepang dalam peningkatan quality. TQM didasarkan pada partisipasi semua anggota organisasi dalam meningkatkan 
proses, produk, jasa, dan budaya dimana mereka bekerja di dalamnya. TQM memberikan keuntungan bagi semua anggota organisasi dan masyarakat. Keuntungan tersebut diperoleh berkat kerjasama semua komponen dalam perusahaan serta adanya komitmen menghasilkan produk yang berkualitas.

Komitmen terhadap quality berakar pada pengalaman, riset, dan tulisan dari beberapa pelopor dan pemimpin pergerakan quality seperti W. Edwards Deming, Joseph M. Juran, Armand V, Feigenbaum, Philip B Crosby, Kaoru Ishikawa Shigeo Shingo, dan Taichi Ohno sejak tahun 1950-an, 1960-an, dan 1970-an (Tunggal, 1993). Dengan demikian, konsep quality sebagai pengembangan dari manajemen sudah ada cukup lama sekitar 50 tahunan.

Dalam perkembangannya, konsep quality di Jepang dikenal dan dikembangkan pasca perang dunia ke-2. Sebagai contoh produk industri mobilnya yaitu Rolls Royce yang bermutu. Sementara Amerika, masalah quality tampak pada industri antariksa dan militer. Crosby (1995) memberi pesan quality yang mengaitkan quality dengan biaya. Selanjutnya, gerakan quality di AS berlangsung terkait mengenai pentingnya komitmen dan perubahan kultural organisasi pada tahun 1980-an. Pada tahun 1987, The Malcolm Baldridge National Quality Improvement Act mengembangkan penghargaan United State National Quality secara tahunan sebagai gambaran keseriusan Amerika Serikat akan masalah quality. Demikian juga di Eropa seperti Inggris, Jerman, Swedia kultur quality sangat kuat (Waller, Allen, \& Burns, 1993).

Kajian teori kualitas dipengaruhi oleh beberapa yang memberikan landasan dalam pengembangan TQM, yaitu W. Edward Deming, Joseph M Juran, dan Philip B. Crosby. Edward Deming yang disebut-sebut sebagai bapak gerakan total quality management mencatat kesuksesan dalam memimpin revolusi kualitas di Jepang dengan memperkenalkan penggunaan teknik pemecahan masalah dan pengendalian proses statistik (statistical process control). Kontribusi Deming dikenal dengan istilah Deming Cycle, Deming Fourteen Points, dan Seven Deadly Diseases (Deming, 1981). Siklus Deming (Deming Cycle) merupakan suatu pemikiran yang terkait dengan proses produksi suatu produk untuk memenuhi kebutuhan pelanggan serta memfokuskan pada sumber daya manusia semua departemen (riset, desain, produksi, pemasaran). Tahap-tahap siklus Deming terdiri dari: perencanaan (plan), menghasilkan produk (do), pemeriksaan (check), pemasaran (act), dan analisis (analyze). Tahap siklus 
Deming di atas menjadi landasan dalam penentuan quality sebuah produk yang dihasilkan oleh sebuah perusahaan.

Sementara itu, (Juran, 1999) memiliki pemikiran berbeda, yang menyatakan bahwa perusahaan dapat mencapai kualitas tingkat dunia apabila melakukan perbaikan struktur berkesinambungan, pelatihan, dan adanya komitmen dan kepemimpinan pada tingkat manajemen yang lebih tinggi. Pemikirannya tentang kualitas dikenal dengan istilah Juran's Ten Steps to Quality Improvement. Sepuluh langkah itu antara lain kesadaran akan perbaikan, pelatihan, penghargaan, dan komunikasi.

Sementara itu, (Crosby, 1995) memiliki pemikiran yang dikenal dengan nama manajemen zero defect dan pencegahan yang menentang tingkat yang dapat diterima secara statistik (acceptable quality level). Pemikiran Crosby dikenal dengan Quality Vaccine dan Crosby's Fourteen Steps to Quality Improvement. Pandangan-pandangan Crosby dirangkum menjadi dalil-dalil manajemen kualitas, yaitu kualitas sama dengan persyaratan (conformance to requirements), Sistem kualitas adalah pencegahan (prevention), kerusakan nol (zero defect), dan the price of non conformance(Crosby, 1995). Selanjutnya (Crosby, 1995) menyatakan bahwa perusahaan harus divaksinasi, yang berupa tiga unsur vaksin kualitas yaitu determination, education, dan implementation. Untuk vaksinasi, perusahaan menyiapkan lima unsur, yaitu integritas, sistem, komunikasi, operasi, dan kebijakan. Semua faktor-faktor tadi harus menjadi prinisp-prinsip manajemen yang terus diupayakan.

\subsubsection{Prinsip-Prinsip Total Quality Management}

Total quality management adalah suatu pendekatan dalam menjalankan usaha yang mencoba untuk memaksimalkan daya saing organisasi melalui perbaikan terus-menerus atas produk, jasa, manusia, proses, dan lingkungannya. Beberapa karakteristik TQM adalah: (1) Fokus pada pelanggan, baik pelanggan internal maupun eksternal; (2) Memiliki obsesi yang tinggi terhadap kualitas; (3) Menggunakan pendekatan ilmiah dalam pengambilan keputusan dan pemecahan masalah; (4) Memiliki komitmen jangka panjang; (5) Membutuhkan kerja sama tim (teamwork); (6) Memperbaiki proses secara berkesinambungan; (7) Menyelenggarakan pendidikan dan pelatihan, memberikan kebebasan yang terkendali; (8) Memiliki kesatuan tujuan; dan (9) Adanya keterlibatan dan pemberdayaan karyawan (Gaspersz, 2008).

Terdapat 4 pilar dasar dalam penerapan TQM, yaitu: (1) Kepuasan konsumen; (2) Perbaikan terus menerus; (3) Hormat terhadap setiap 
orang; dan (4) Manajemen berdasarkan fakta. Setiap konsumen yang diambil akan memberikan hasil yang memuaskan jika didasarkan pada data dan informasi objektif, lengkap dan akurat (Juran \& Godfrey, 1998).

Agar penerapan TQM memperoleh keberhasilan, perusahaan harus memiliki pedoman yang jelas dan terarah. Dalam penerapan TQM, perusahaan bisa mengacu pada atribut efisiensi yaitu (Tunggal, 1993):

1. Commitment, untuk menyediakan produk atau layanan yang efisien dan menguntungkan harus ditunjukkan oleh manajemen dan perusahaan;

2. Concistency, perusahaan harus menyediakan produk dengan kinerja yang konsisten, misalnya ketepatan spesifikasi, ketepatan jadwal, dan lain-lain;

3. Competence, perusahaan harus menyediakan pekerja dengan kemampuan atau kompetensi unggul untuk melaksanakan tugas-tugas atau pekerjaan yang diberikan, sehingga mendukung pencapaian sasaran perusahaan;

4. Contact, perusahaan harus mampu menjalin hubungan baik dengan konsumen, karena tujuan perusahaan adalah menyediakan produk yang sesuai dengan harapan dan keinginan konsumen;

5. Communication, perusahaan harus mampu menjalin komunikasi yang baik dengan konsumen, agar spesifikasi produk yang diinginkan konsumen bisa diterjemahkan dengan baik oleh perusahaan;

6. Credibility, perusahaan harus memperoleh kepercayaan dari konsumen dan juga harus mempercayai konsumen. Dengan adanya saling percaya, hubungan dan komunikasi akan terjalin dengan baik;

7. Compassion, perusahaan harus memiliki rasa simpati terhadap konsumen eksternal, terutama menyangkut kebutuhan dan harapan mereka, dan konsumen internal (pekerja) menyangkut hak pekerja;

8. Courtesy, perusahaan melalui para pekerja harus menunjukkan sikap sopan kepada konsumen, terutama bekerja yang langsung berhubungan dengan konsumen;

9. Coorperation, perusahaan harus bisa menciptakan iklim kerjasama yang baik, antar pekerja maupun antara perusahaan dengan konsumen;

10. Capability, perusahaan harus memiliki kemampuan untuk melakukan pengambilan keputusan dan melakukan tindakan yang berkaitan dengan penyedia produk atau layanan;

11. Confidence, perusahaan harus memiliki rasa percaya diri bahwa perusahaan mampu menyediakan produk atau layanan sesuai 
kebutuhan dan harapan konsumen. Rasa percaya diri harus tertanam ke dalam seluruh pekerja; dan

12. Criticism, perusahaan harus bersedia menerima kritik dan masukan dari siapapun, baik dari pekerja maupun dari pihak eksternal, terutama kritik dari konsumen.

Sementara itu, menurut (Render \& Heizer, 2004) terdapat 5 (lima) konsep program TQM yang efektif yaitu: perbaikan berkelanjutan, pemberdayaan karyawan, perbandingan kinerja (benchmarking), penyediaan kebutuhan tepat pada waktunya, dan pengetahuan tentang piranti TQM.

Dalam pengelolaan kualitas, dilakukan melalui penggunaan tiga proses manajemen, yaitu:

1. Perencanaan kualitas: aktivitas pengembangan produk dan proses yang dibutuhkan untuk memenuhi kebutuhan pelanggan.

2. Pengendalian kualitas: aktivitas evaluasi kinerja kualitas, membandingkan kinerja nyata dengan tujuan kualitas, dan bertindak berdasarkan perbedaan.

3. Peningkatan kualitas: cara-cara meningkatkan kinerja kualitas ke tingkat yang lebih dari sebelumnya.

Dalam perkembangannya prinsip-prinsip TQM bukan sekedar pendekatan proses dan struktur sebagaimana dijelaskan sebelumnya, TQM lebih merupakan pendekatan kesisteman yang juga melibatkan aktivitas manajemen sumber daya manusia. Upaya tersebut dapat dilakukan melalui pendidikan dan pelatihan, pendekatan system pengupahan yang mendukung, dan struktur kerja.

\subsubsection{Penerapan Total Quality Management pada Lembaga Keuangan Syariah}

Di Indonesia, industri keuangan syariah sudah lebih dari dua windu. Kalau diibaratkan manusia adalah bagaikan usia seorang remaja yang hendak menginjak pemuda. Keberadaan industri perbankan syariah yang dipertegas dengan lahirnya undang-undang perbankan syariah nomor 21 tahun 2008 memiliki perbedaan operasional dengan perbankan konvensional yaitu perbankan yang beroperasi dengan prinsip-prinsip syariah.

Menurut (Musari, 2010) untuk merespon dengan efektif berbagai tantangan yang ada, penciptaan sistem yang memenuhi level "quality" yang sesuai dengan konsep syariah menjadi isu vital nyata yang menantang. Salah satu tuntutan global agar industri keuangan syariah mampu bersaing 
adalah terciptanya mutu. Mutu hanya bisa dicapai melalui sebuah perbaikan terus-menerus. Intisari dari Total Quality Management sebenarnya sejalan dengan nilai-nilai yang diajarkan Islam. Namun, belum banyak kajian yang intensif menyelidiki keterkaitan dan kesesuaian teori-teori TQM kontemporer dengan prinsip-prinsip syariah. Kebanyakan organisasi berbasis syariah mengadopsi secara total model-model TQM kontemporer beserta turunannya. Namun, sejumlah organisasi lainnya sudah mulai mencoba mengembangkan model-model baru yang disesuaikan dengan prinsip-prinsip syariah.

Ada dua pendekatan yang bisa digunakan, yaitu pendekatan inisiasi dan pendekatan adopsi konstruksi. Mengingat butuh waktu bagi pemikirpemikir konsep mutu syariah untuk menciptakan sesuatu yang baru dan dapat diterima masyarakat global, maka sebagai akselerasi mengejar ketertinggalan banyak yang menggunakan pendekatan adopsi konstruksi. Melalui pendekatan ini, model-model TQM syariah cenderung lebih mudah dipahami dan cepat diterima oleh dunia global. Dari hasil pendekatan adopsi-konstruksi, sejumlah model TQM syariah mulai diperkenalkan, utamanya dalam penciptaan sistem manajemen mutu (Quality Management System/QMS) syariah.

Othman dan Owen (2005) menjelaskan penelitian model kualitas pelayanan di industri perbankan Islam. Penelitian tersebut mengembangkan instrumen untuk mengukur kualitas pelayanan pada industri perbankan Islam dengan menggunakan enam dimensi yang dinamakan CARTER (Compliance fully with Islamic law and principles, Assurance, Reliability, Tangibles, Empathy, and Responsiveness) (Othman \& Owen, 2005).

Jika kita memperhatikan seluruh aspek dalam TQM, maka akan tampak bahwa TQM adalah aplikasi dari ajaran Islam. Intisari dari TQM berupa perbaikan berkelanjutan tercermin dalam Al-Qur'an Surat ArRa'du ayat 11:

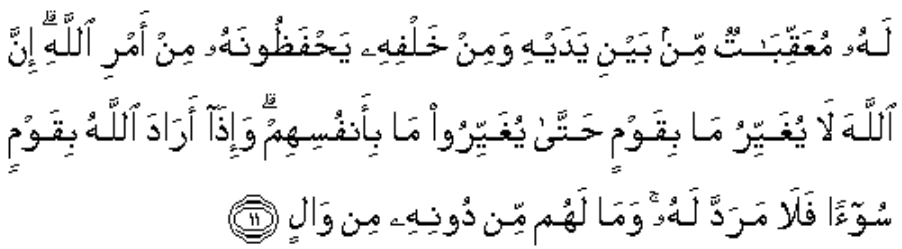

Artinya: "Sesunggubnya Allah tidak merobah Keadaan sesuatu kaum sehingga mereka merobah keadaan yang ada pada diri mereka sendiri."

Ajaran ini didukung pula dalam Al-Qur'an surat al-Insyiroh ayat 7 yang artinya "Maka apabila kamu telah selesai (dari sesuatu urusan), kerjakanlah 
dengan sungguh-sungguh (urusan) yang lain". Dalam ayat tersebut, Islam menyuruh kita untuk bekerja sungguh-sungguh atau bekerja dengan performa yang bermutu. Selain itu, Allah sangat mencintai perbuatanperbuatan yang terorganisasi dengan baik, sebagaimana dijelaskan dalam Al-Qur'an surat ash-shaff ayat 4: yang artinya: "Sesunggubnya Allah menyukai orang yang berperang dijalan-Nya dalam barisan yang teratur seakan-akan mereka seperti suatu bangunan yang tersusun kokob."

Konsep manajemen mutu juga semakin ditegaskan dalam Islamic International Rating Agency (IIRA) dengan menjadikan aspek-aspek manajemen mutu sebagai salah satu kriteria evaluasi dalam Sharia Quality Rating (SQR). Kriteria evaluasi SQR meliputi Sharia Committee, Internal Sharia Control, Accounting Standards, Training and Human Resources, Zakat, Social Impact, Modes of Financing, Identity and Corporate Image (Zaidi, 2006).

Di Bahrain, model Quality Management System (QMS) sudah mulai banyak diterapkan oleh perbankan syariah. Model QMS yang memang didesain dan dikonstruksikan untuk perbankan syariah ini meliputi elemen-elemen sebagai berikut (Saleh, 2005).

Gambar 2.1. Kerangka Sistem Manajemen Kualitas Model Bisnis dalam Sektor Perbankan Syariah

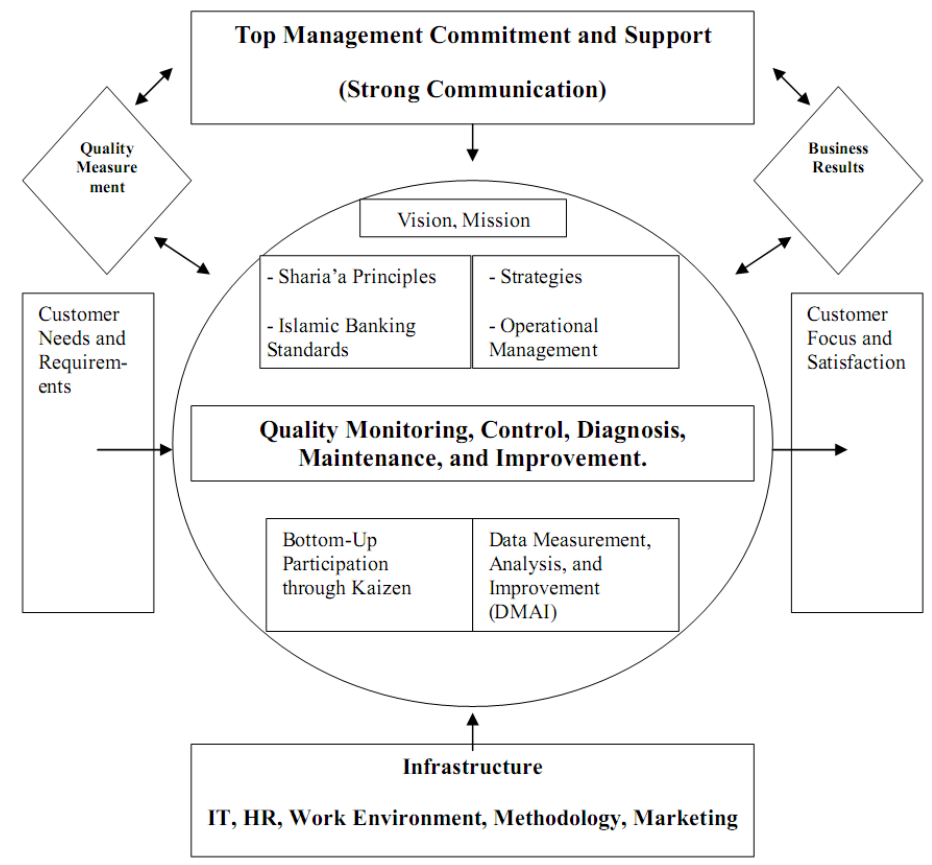

Sumber: (Saleh, 2005) 
Pada gambar di atas menunjukkan model QMS yang diterapkan pada perbankan syariah di Bahrain. Model QMS tersebut memuat 8 (delapan) elemen yaitu management leadership and commitment, Islamic bank direction and contribution; including vision, mission, strategic direction, market focus, and distinguished tactics, customer focus a one of the driving force, core business through Sharia principles and its compliance, quality practice tools and methodologies, bottom up contribution (through employees), competitive infrastructure, data measurement, analysis, and improvements

Kepemimpinan manajemen yang kuat sangat berpengaruh pada kemampuan perusahaan memimpin pasar. Seorang pemimpin perusahaan harus mengetahui kebutuhan orang-orang yang terlibat dalam perusahaan dan secara bersama-sama menjadikan kebutuhan stakeholder perusahaan menjadi tujuan bersama organisasi. Manajer harus paham dan menganalisis pengaruh mengetahui tujuan bisnis organisasi dengan nilai yang diyakini dalam praktek kerja bersama-sama dengan anggota organisasi.

Bank syariah sebaiknya memasukan visi yang islami selain tujuan komersilnya. Membangun visi, misi, taktik adalah strategi awal perencanaan, tetapi ini tidak bisa diwujudkan jika tidak didukung oleh orang-orang yang bekerja dalam bank. Dalam pengembangan ini, penyebaran visi, misi dan strategi oleh manajemen puncak menjadi isu penting.

Bank yang menjalankan operasinya berdasarkan prinsip syariah harus dipastikan prakteknya sesuai yang dikehendaki oleh prinsip syariah. Organisasi bisnis biasanya memiliki departemen kualitas dan internal audit untuk memastikan praktek yang berjalan sesuai dengan yang dikehendaki oleh kebijakan organisasi. Hal ini juga berlaku pada industri perbankan yang memiliki departemen internal audit yang melaksanakan tugas tersebut diatas. Di sisi lain, perbankan syariah selain harus menyediakan departemen internal audit, juga harus bersama-sama menjalankan tugas untuk memeriksa kepatuhan operasi bisnis terhadap praktek dan standar syariah.

Dalam model sistem manajemen mutu diatas, salah satu yang sangat esensial adalah melibatkan tingkat bawah dalam manajemen perbankan untuk berpartisipasi dalam mengembangkan dan meningkatkan praktek dan keadaan sekitar mereka untuk meningkatkan produk dan jasa langsung dengan mudah. Perbaikan kinerja tim bukanlah aktivitas yang dipaksakan, tetapi keyakinan dan perubahan budaya yang akan 
menentukan. Perubahan tersebut bisa dilakukan melalui komitmen dari manajemen puncak kepada seluruh orang di dalam bank. Selain itu, yang paling penting disini adalah manajemen membuat peraturan dan regulasi untuk aktivitas sukarela dari karyawannya untuk diberikan penghargaan karena telah membantu mengimplementasikan produk dan jasa perbankan syariah dengan baik.

Untuk memperoleh transformasi dan peluasan layanannya kepada pelanggan internasional, bank syariah membutuhkan infrastruktur teknologi informasi kelas dunia, disamping infrastruktur lainnya seperti lokasi, lingkungan kerja, dan persyaratan lain yang diperlukan untuk meningkatkan profesionalisme sumberdaya. Infrastruktur teknologi informasi yang kompetitif harus bisa mengakomodasi pertumbuhan jumlah nasabah dan volume transaksi tanpa menyebabkan dampak yang negatif kepada kinerja.

Peran teknologi informasi dalam perbankan syariah mempertimbangkan bagaimana kontrak dapat dideteksi saat tidak mematuhi prinsip syariah. Infrastruktur harus diidentifiksi dan dikendalikan agar tidak terjadi ketidakpuasan nasabah. Selanjutnya, sumber daya tidak lengkap tanpa mempertimbangkan lingkungan kerja. Kondisi kerja dapat mempengaruhi kualitas produk dan jasa, oleh karena itu harus dikendalikan. Selain itu, juga penting untuk meningkatkan kualitas mutu yaitu memiliki alat analisis pemasaran dan data yang dapat diubah menjadi informasi yang bernilai.

\subsection{Kualitas Sumber Daya Manusia}

Sumber Daya manusia atau hal yang berkaitan dengan "orang" dalam suatu organisasi merupakan masalah yang penting. SDM merupakan bagian yang penting dari sebuah perusahaan untuk mendapatkan ISO 9000 (Dessler, 2012). Manusia sebagai tenaga kerja adalah bagian dari manajemen yang memiliki peran sangat penting dalam menjalankan roda sebuah organisasi atau perusahaan (Stoner \& Freeman, 1995).

Dalam kegiatan perusahaan atau organisasi moderm, manajemen sumber daya manusia memiliki peran strategis untuk meningkatkan kinerja organisasi atau perusahaan (Bartol \& Martin, 1998). Manajemen sumber daya manusia merupakan kegiatan yang dilakukan berkaitan dengan "orang" atau sumber daya manusia dari posisi seorang manajer yang meliputi perekrutan, penyaringan, pelatihan, pemberian upah, dan penilaian kinerja (Dessler, 2012). 
Berbicara tentang konsep mutu SDM, berarti mengidentifikasi sumber daya manusia. Manajemen SDM yang berhubungan dengan tenaga kerja mulai dari input, proses sampai pada output. Input antara lain mencakup: tingkat pendidikan, keterampilan atau manajerial, pengalaman kerja, kedisiplinan, kejujuran, motivasi, sikap, dan kesehatan mental maupun fisik (Dessler, 2012).

\subsection{Variabel Penelitian}

\subsubsection{Total Quality Management}

Variabel independen dari penelitian ini adalah Total Quality Management. Gaspersz (2008) mendefinisikan Total Quality Management (TQM) sebagai suatu cara meningkatkan performa secara terus menerus pada setiap level operasi atau proses, dalam setiap area fungsional dari suatu organisasi dengan menggunakan semua sumber daya manusia dan modal yang tersedia. Variabel TQM pada penelitian ini menggunakan sub variabel yang dikembangkan oleh Saleh (2005).

Dari sub variabel tersebut, dikembangkan menjadi instrumen variabel yang terdiri dari 17 butir pertanyaan. Variabel ini dikelompokkan menjadi 3 indikator, yaitu indikator Kualifikasi dan Standar SDM, Sistem Pengelolaan Manajemen, serta indikator Ketersediaan Sarana. Indikator Kualifikasi dan Standar SDM terdiri dari 7 (tujuh) instrumen pertanyaan, sementara indikator Sistem Pengelolaan Manajemen terdiri dari 4 (empat) instrumen pertanyaan, sedangkan indikator Ketersediaan Sarana terdiri dari 6 (enam) instrumen pertanyaan. Seluruh instrumen variabel diukur dengan menggunakan skala likert 5 poin dari Sangat Tidak Setuju (1), Tidak Setuju (2), Netral (3), Setuju (4) sampai Sangat Setuju (5).

Tabel 3.1. Operasional Variabel Penelitian

\begin{tabular}{|c|c|c|}
\hline Variabel & Indikator & Pengukuran \\
\hline \multirow{9}{*}{$\begin{array}{l}\text { Total Quality } \\
\text { Management }\end{array}$} & \multirow{7}{*}{$\begin{array}{c}\text { Kualifikasi dan } \\
\text { Standar SDM }\end{array}$} & $\begin{array}{l}\text { Memahami nilai-nilai moral dalam aplikasi Fiqh } \\
\text { Muammalah }\end{array}$ \\
\hline & & $\begin{array}{l}\text { Memahami konsep dan tujuan Lembaga Keuangan } \\
\text { Syariah }\end{array}$ \\
\hline & & Memahami konsep dan aplikasi transaksi (akad) \\
\hline & & Mengenal dan memahami mekanisme kerja lembaga \\
\hline & & $\begin{array}{l}\text { Mengetahui dan memahami mekanisme kerja serta } \\
\text { interaksi lembaga-lembaga terkait }\end{array}$ \\
\hline & & $\begin{array}{l}\text { Mengetahui dan memahami hukum dasar (hukum } \\
\text { Syariah dan hukum Positif) }\end{array}$ \\
\hline & & Menguasai bahasa sumber ilmu (Arab dan Inggris) \\
\hline & \multirow{2}{*}{ Sistem } & Dilaksanakannya forum dengan stakeholer secara rutin \\
\hline & & Dilaksanakannya sistem perbaikan pengelolaan \\
\hline
\end{tabular}




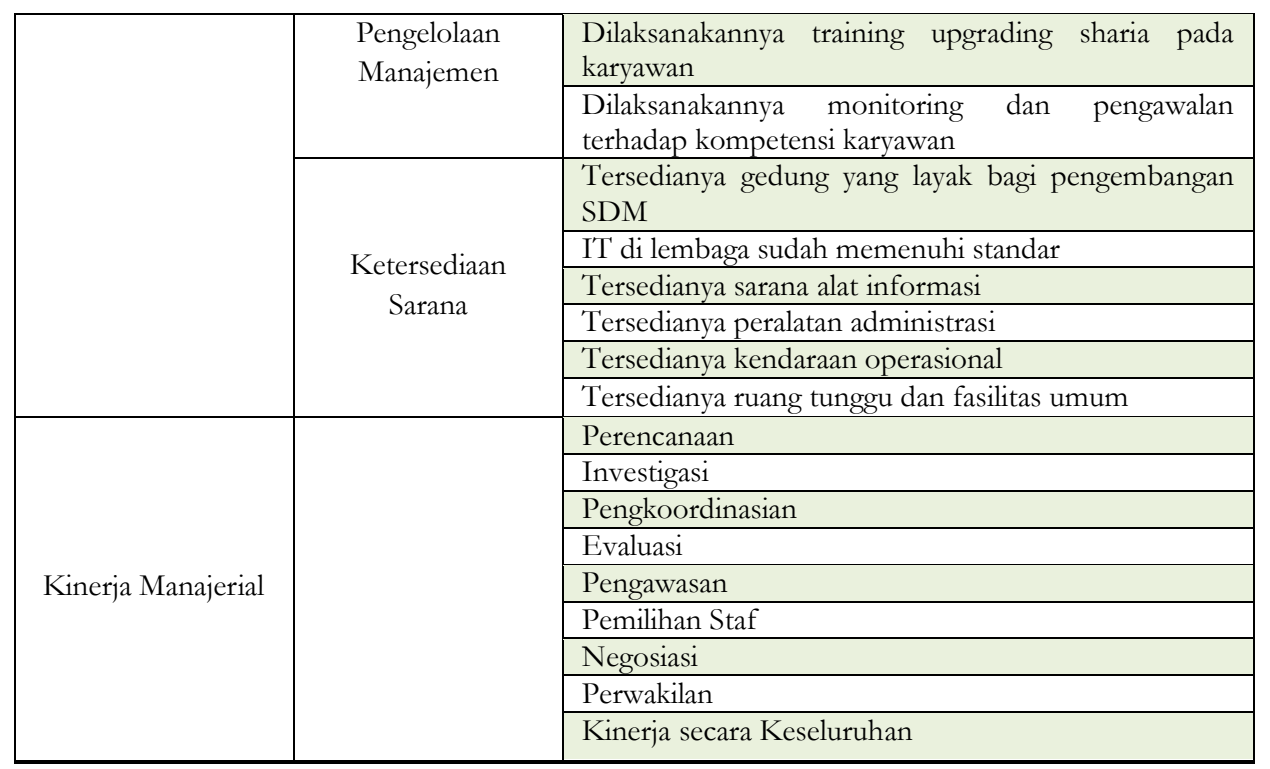

\subsection{Metode Analisis Data}

\subsubsection{Analisis Deskriptif/Kualitatif}

Penelitian ini menggunakan metode analisis deskriptif untuk menjelaskan keragaan keterkaitan penguatan manajemen syariah melalui penerapan TQM dengan kinerja manajerial BMT. Penelitian ini dapat juga dikatagorikan sebagai penelitian eksploratif dan evaluatif. Untuk mengetahui keragaan Bank Syariah dan BMT secara keseluruhan, analisis difokuskan pada 3 (tiga) aspek, yaitu pertama aspek kualifikasi dan standar SDM, kedua aspek sistem Pengelolaan Manajemen, dan ketiga aspek ketersediaan sarana. Variabel-variabel yang termasuk dalam keragaan kinerja mencakup: Data-data dikumpulkan dan di analisis secara deskriptif kuntitatif dan positioning. Pendiskripsian keragaan penguatan manajemen syariah BMT ditampilkan dalam bentuk diagram dan tabulasi.

\subsubsection{Analisis Keterkaitan}

Penguatan manajemen syariah melalui penerapan TQM dalam menunjang kinerja manajerial BMT dapat dilihat dari keterkaitan diantara keduanya. Keterkaitan tersebut dapat dilihat dari sejauh penguatan manajemen syariah melalui penerapan TQM dalam melaksanakan fungsifungsinya yang pada ujungnya akan berdampak pada peningkatan kinerja manajerial BMT. Penelusuran mengenai keterkaitan antara penguatan manajemen syariah dengan kinerja BMT atau sebaliknya dilakukan melalui berbagai fungsi yang dianggap selayaknya diterapkan oleh BMT. Fungsifungsi ini dihimpun dari hasil diskusi beberapa kali dengan para pakar 
BMT (focus group discussion/FGD). Fungsi-fungsi tersebut dikelompokkan menjadi (1) fungsi kualifikasi dan standar SDM, (2) fungsi sistem pengelolaan manajemen, dan (3) fungsi ketersediaan sarana. Definisi fungsi disajikan pada Tabel 3.1.

\subsubsection{Uji Chi Square (Uji $\left.\chi^{2}\right)$}

Keterkaitan antara penguatan manajemen syariah melalui penerapan TQM dalam menunjang kinerja manajerial BMT dianalisis dengan metode Chi-Square (uji $\chi^{2}$ ) dengan rumus sebagai berikut:

$\chi^{2}=\sum \frac{\left(f_{0}-f_{h}\right)^{2}}{f_{h}}$

keterangan:

$\chi^{2} \quad:$ Cbi Square

$\mathrm{f}_{0} \quad$ : Frekuensi yang diperoleh dari sampel (hasil observasi)

$f_{h} \quad$ : Frekuensi yang diharapkan atau disebut juga frekuensi teoritis.

Chi Square (Uji $\chi^{2}$ ) merupakan teknik statistik yang memungkinkan peneliti menilai probabilitas memperoleh perbedaan frekuensi yang nyata dengan frekuensi yang diharapkan dalam kategori-kategori tertentu. Uji Chi-Square adalah uji independensi, dimana suatu variabel tidak dipengaruhi atau tidak ada hubungan dengan variabel lain.

Untuk mendapatkan nilai Chi-Square, ditempuh beberapa langkah yakni (1) data frekuensi ditabulasi, (2) dihitung frekuensi yang diharapkan (frekuensi teoritis), dan (3) menghitung nilai Uji Cbi-Square berdasarkan rumus (1). Untuk menghitung nilai dari frekuensi yang diharapkan (frekuensi teoritis), digunakan rumus pada persamaan (2).

$f_{\varepsilon}=\frac{(\Sigma f \text { Kolom })(\Sigma f \text { Baris })}{\text { Total }}$

keterangan:

$f_{e} \quad=$ Frekuensi yang diharapkan (frekuensi teoritis)

$\Sigma f$ kolom $=$ Jumlah frekuensi kolom

$\Sigma f$ baris $\quad=$ Jumlah frekuensi baris

Total = Jumlah baris dan kolom (keduanya harus sama).

\subsubsection{Uji Signifikansi}

Uji siginifkansi digunakan untuk menunjukkan bahwa apakah teradapat hubungan yang signifikan ataukah tidak antara satu variabel dengan variabel lainnya. Dalam penelitian ini, uji signifikansi digunakan untuk mengetahui apakah ada hubungan yang signifikan antara Penguatan manajemen syariah melalui penerapan TQM dengan kinerja manajerial melalui fungsi-fungsi dari penerapan TQM. Hipotesis yang digunakan 
adalah hipotesis nol/nihil $\left(\mathrm{H}_{0}\right)$ dan hipotesis tandingan/alternatif $\left(\mathrm{H}_{2}\right) . \mathrm{H}_{0}$ berarti tidak ada keterkaitan antara penguatan manajemen syariah melalui penerapan TQM dengan kinerja manajerial BMT. $\mathrm{H}_{\mathrm{a}}$ berarti terdapat keterkaitan antara penguatan manajemen syariah dengan kinerja manajerial, secara statistik dinyatakan bahwa:

$\mathrm{H}_{0}$ diterima bila $\quad: \chi^{2} \leq \chi^{2}$ a: dengan derajad bebas tertentu

$\mathrm{H}_{0}$ ditolak atau terima $\mathrm{H} 1$ bila $\quad: \quad \chi^{2}>\chi^{2} a$ : dengan derajad bebas tertentu

Terima $\mathrm{H}_{0}$ memiliki arti tidak ada keterkaitan yang signifikan antara penguatan manajemen syariah dengan kinerja manajerial. Sebaliknya $\mathrm{H}_{0}$ ditolak atau terima $\mathrm{H}_{a}$ berarti terdapat keterkaitan yang signifikan antara kedua variabel. Nilai $\chi^{2}$ diperoleh dari hasil perhitungan sesuai rumus $c b i$ square di atas. Sedangkan nilai $\chi^{2}$ a dengan derajad bebas tertentu adalah nilai chi square statistik yang dapat dilihat pada tabel chi square standar. Derajad bebas (d.b) diperoleh dengan rumus:

\section{(Jumlah baris -1) dikalikan (jumlah kolom - 1)}

Taraf signifikansi yang digunakan dalam penelitian ini adalah $\alpha=$ 0.05 yang memiliki arti kita percaya bahwa 95\% hasil uji yang kita peroleh adalah sangat akurat. Yakni jika sesuai hasil uji kita terima $\mathrm{H}_{1}$ maka berarti sebesar 95\% kita percaya bahwa terdapat hubungan yang sangat kuat antara Bank Syariah dengan BMT.

\subsubsection{Koefisien Kontingensi (C)}

Koefisien Kontingensi digunakan untuk mengukur derajat hubungan, asosiasi, atau dependensi dari klasifikasi-klasifikasi dalam Tabel Kontingensi. Derajat hubungan disini menunjukkan ada korelasi atau tidak antara kolom dan baris Tabel Kontingensi, dan apakah hubungan tersebut kuat atau tidak kuat. Rumus koefisien kontingensi adalah:

$c=\sqrt{\frac{\chi^{2}}{\chi^{2}+n}}$

keterangan:

$\mathrm{C}=$ Koefisien kontingensi

$\chi^{2}=$ Nilai chi-square

$\mathrm{n} \quad=$ Besar sampel

Nilai koefisien kontingensi (C) berkisar antara nol hingga satu. Jika $\mathrm{C}=0$ maka tidak terdapat keterkaitan antara penguatan manajemen 
syariah dengan kinerja manajerial. Jika $\mathrm{C}=1$ maka terdapat keterkaitan yang sangat kuat diantara keduanya. Adapun pengambilan keputusan mengenai kuat atau lemahnya hubungan keterkaitan antara kedua variabel tersebut, dilakukan berdasarkan Tabel 3.2.

Tabel 3.2. Kuat/Lemah Keterkaitan antara 2 Variabel

\begin{tabular}{|c|c|}
\hline $\begin{array}{c}\text { Interval Keterkaitan } \\
\text { Koefisien kontingensi (c) }\end{array}$ & Tingkat Hubungan \\
\hline $0,00-0,199$ & Sangat Lemah \\
\hline $0,20-0,399$ & Lemah \\
\hline $0,40-0,599$ & Sedang \\
\hline $0,60-0,799$ & Kuat \\
\hline $0,80-1,000$ & Sangat Kuat \\
\hline \multicolumn{2}{|r}{ Sumber: (Gujarati, 2009) } \\
\hline
\end{tabular}

\subsection{Deskripsi Responden dan Data Penelitian}

\subsubsection{Tingkat Pengembalian Kuesioner}

Pedekatan análisis pada studi ini adalah deskriptif kuantitatif, data penelitian studi ini menggunakan data primer yang berasal dari jawaban responden atas jawaban pertanyaan-pertanyaan pada kuesioner penelitian. Pendistribusian kuesioner dilakukan langsung kepada responden melalui kontak person, demikian juga halnya pengembalian kuesioner dari responden.

Kuesioner yang diisi dan kembali yang berasal dari responden di 10 BMT di wilayah Kota Semarang adalah sebanyak 41 kuesioner. Setelah dilakukan penyortiran data atas jawaban responden ditemukan 4 responden tidak mengisi kuesioner penelitian secara lengkap. Kuesioner yang tidak lengkap tersebut tidak diikutkan dalam analisis data selanjutnya. Dengan demikian jumlah sampel penelitian ini adalah 37 responden dengan tingkat pengembalian efektif adalah $74 \%$. Tingkat pengembalian kuesioner sebesar $74 \%$ persen dipertimbangkan juga cukup memadai (Otley dan Pierce, 1996) serta memperhatikan tingkat pengembalian untuk ukuran Indonesia yang rata-rata hanya 10-20 persen (Indriantoro dan Supomo, 1999).

Tabel 4.1. Rincian Pengiriman dan Pengembalian Kuisioner

Keterangan $\quad$ Jumlah data




\begin{tabular}{lc}
\hline \hline Jumlah Kuisioner yang didistribusikan & 50 \\
\hline Jumlah Kuisioner yang kembali & 41 \\
\hline Jumlah Kuisioner yang tidak dapat digunakan & 4 \\
\hline Jumlah Kuisioner yang dapat digunakan & 37 \\
\hline Tingkat pengembalian (Respon rate) $41 / 50 \times 100 \%=82 \%$ & \\
\hline Tingkat pengembalian yang digunakan (Usable respon rate) $37 / 50 \times 100 \%=$ \\
$74 \%$
\end{tabular}

Sumber: Data Primer Yang Diolah, 2016.

\subsection{Pembahasan}

Permasalahan dalam hal penguatan manajemen syariah pada Lembaga Keuangan Syariah di dapat dikelompokkan menjadi 3 aspek yang terdiri dari aspek sumber daya manusia (SDM), aspek infrastruktur, dan aspek manajemen.

Permasalahan Kualifikasi dan Standar Sumber Daya Manusia (SDM), disebabkan karena adanya dikotomi antara sistem pendidikan syariah dan pendidikan umum yang menyebabkan adanya dualisme intelektual. Selain itu juga masyarakat pada umumnya belum familiar dengan praktik Lembaga Keuangan Syariah. Permasalahan SDM ini dibagi menjadi tiga sub yaitu:

a. Lemahnya pemahaman praktisi Lembaga Keuangan Syariah, baik sisi pengembangan bisnis maupun sisi syariah.

Pengelola Lembaga Keuangan Syariah masih banyak yang belum memahami tentang prinsip-prinsip syariah dan prinsip pengelolaan usaha yang baik dan benar. Dengan demikian, belum terpenuhinya sumber daya manusia yang berkualitas di bidang ekonomi syariah berdampak pada potensi terjadinya penyimpangan atas prinsip syariah dalam praktik Lembaga Keuangan Syariah.

b. Secara umum sumber daya insani yang dimiliki Lembaga Keuangan Syariah relatif belum profesional layaknya lembaga keuangan seperti perbankan yang relatif besar.

c. Jumlah SDM di Lembaga Keuangan Syariah masih terbatas sehingga kurang maksimal dalam pelayanan dalam bekerja. Kekurangan menyebabkan perekrutan karyawan yang kurang kompetitif sehingga tidak dapat mendapatkan karywan yang berkualitas.

Selanjutnya adalah permasalahan yang terkait dengan sistem pengelolaan manajemen, terkait dengan ketentuan hukum dan sistem pengawasan atau pembinaan. Permasalahan manajemen meliputi 3 sub 
yaitu: 1) Manajerial lembaga Lembaga Keuangan Syariah masih lemah yang berimbas pada kinerja lembaga Lembaga Keuangan Syariah. 2) Manajemen funding/penghimpunan dana belum optimal karena sumber dana yang ada masih terbatas dan kecil. 3) Pelayanan kurang maksimal yang mengakibatkan masyarakat kurang berminat untuk memakai jasa Lembaga Keuangan Syariah.

Pada aspek teoritis dan konseptual, Lembaga Keuangan Syariah masih kekurangan SDM yang benar-benar mendalami ilmu ushul fikih, fikih muamalah, qawa'id fikih dan sekaligus ilmu ekonomi keuangan modern. Kebanyakan SDM LKS saat ini adalah mereka yang fasih berbicara tentang ilmu ekonomi keuangan kontemporer, tetapi belum memahami masalah ushul figh atau fiqh muamalah. Sebaliknya banyak pakar yang mahir dalam Fikih dan Usul Figh tetapi kurang memahami (kalau tidak ingin mengatakan buta) tentang Ilmu Ekonomi Keuangan.

Untuk melahirkan SDM yang berkompeten di bidang ekonomi, bisnis dan hukum ekonomi syari'ah secara komprehensif dan memadai, serta memiliki integritas moral tinggi, maka dibutuhkan lembaga pendidikan ekonomi syari'ah yang secara khusus menyiapkan SDM ekonomi syari'ah. Perlu ada linkage program antara akademisi dan praktisi LKS, sehinga pelaku mempunyai skills tentang ekonomi syari'ah dan memiliki budi pekerti yang sesuai dengan syariah Islam dan applicable di sektor ekonomi.

Adapun alternatif solusi yang dapat dilakukan dalam hal penguatan manajemen syariah pada Lembaga Keuangan Syariah antara lain Training intensif untuk SDM dan penggerak Lembaga Keuangan Syariah, sehingga SDM mempunyai kelebihan dan kemampuan yang handal dalam menjalankan Lembaga Keuangan Syariah. Selain itu, juga diintensifkan seleksi komprehensif atas SDM Lembaga Keuangan Syariah sehingga menghasilkan SDM yang benar-benar siap untuk bekerja di bidang Lembaga Keuangan Syariah.

Sementara itu alternatif solusi lain bisa juga dilakukan dengan peningkatan kapasitas (kemampuan) manajemen melalui beberapa pelatihan manajerial seperti aspek ekonomi dan manajemen keuangannya sehingga mampu membawa lembaga Lembaga Keuangan Syariah menjadi lebih berkembang. Memperluas cakupan sumber dana dengan cara memperoleh kepercayaan dari masyarakat terlebih dahulu sehingga mereka mempunyai kemauan untuk menaruh dananya pada lembaga Lembaga Keuangan Syariah yang mempunyai prinsip amanah (trust), contohnya 
melalui ketokohan dalam masyarakat. Peningkatan SOP pelayanan diharapkan akan menjadikan lembaga Lembaga Keuangan Syariah menjadi lebih tertata dan teratur.

Terkait dengan ketersediaan sarana, beberapa solusi yang bisa dilakukan adalah melakukan upgrading system/jaringan melalui pemberian kesempatan dan kewenangan untuk mengelola potensipotensi ekonomi serta memberikan kemudahan bagi lembaga keuangan konvensional untuk melakukan konversi menjadi lembaga Lembaga Keuangan Syariah. Selain itu juga dengan cara menciptakan produk dan layanan yang inovatif dengan cara mengikuti tren perkembangan lingkungan bisnisnya, sehingga tidak ketinggalan inovasi produknya agar bisa merebut pasar/menarik minat masyarakat untuk memakai jasa lembaga Lembaga Keuangan Syariah, misalnya produk yang akomodatif terhadap keperluan nasabah dan kompetitif dalam dunia perbankan (bagi hasilnya tinggi jika menyimpan uang). Solusi lain adalah meningkatkan kerjasama melalui asosiasi yang bertujuan untuk memperkuat keberadaan Lembaga Keuangan Syariah serta untuk wadah sharing permasalahan atau strategi dalam memperkuat lembaga Lembaga Keuangan Syariah.

Minimnya skills dan kognisi (keilmuan) praktisi di bidang perbankan syariah ini menimbulkan dampak negatif yang berkelanjutan, antara lain implementasi syariah Islam dalam perbankan menjadi tidak optimal. Kekhawatiran praktek bank syari'ah telah tercemar oleh budaya konvensional yang tidak syar'i yang bertentangan dengan fitrah alam dan fitrah usaha.

Pada Level top manajemen yang ada banyak kecenderungan pada comfort zona atau merasa cukup yang dengan keahlian teknis bekal dari bank konvensioanal, akibatnya untuk dirinya sendiri tidak melakukan penguatan kesyariaahan dan mengakibatkan akselari program terhadap penguatan manajemen syariah dibawahnya dilakukan tidak serius. Sehingga semakin jauh dari visi dan misi bank syariah. Misalnya pembiayaan mudharabah dan musyarakah yang seharusnya menjadi ruh bank syariah dan menjadi pembeda yang jelas dan sekaligus positioning yang pontensional untuk bersaing antara konvensional dan syariah, malah semakin dijauhi karena alasan beban target bisnis yang sempit oleh para stakeholder.

Beberapa strategi atas identifikasi masalah yang dilakukan dalam penguatan manajemen syariah Lembaga Keuangan Syariah adalah membuat aturan yang memperkuat posisi dan keberadaan lembaga 
Lembaga Keuangan Syariah seperti adanya undang-undang atau peraturan yang mengatur sehingga dalam melaksanakan kegiatannya lembaga Lembaga Keuangan Syariah tidak terkendala pada hal-hal yang membatasi atau menghalanginya. Selain regulasi yang memperkuat posisi dan keberadaan LKS, juga diperlukan optimalisasi peran Dewan Pengawas Syariah (DPS) melalui peningkatan pengawasan terhadap lembaga Lembaga Keuangan Syariah serta lebih intens dalam memberikan masukan dan saran kepada direksi atau pengurus lembaga Lembaga Keuangan Syariah. Hal lain yang juga perlu dipertimbangkan adalah membentuk modal sosial yaitu berdasarkan banyaknya masyarakat pemeluk agama islam atau kerjasama dengan ormas Islam Indonesia. Implementasinya dengan membangun kepercayaan masyarakat tentang prinsip lembaga Lembaga Keuangan Syariah yang amanah dan islami (sesuai syar'i).

\subsection{KESIMPULAN}

Berdasarkan hasil penelitian dan pembahasan dapat disimpulkan beberapa hal sesuai dengan hipotesis sebagai berikut:

1. Dari hasil penelitian mengenai penguatan manajemen syariah melalui penerapan total quality management pada Lembaga Keuangan Syariah di Kota Semarang, bahwa penerapan total quality management secara ratarata menunjukkan kategori "baik". Meskipun demikian terdapat beberapa instrumen yang mempunyai kategori kurang baik/sedang, seperti pada indikator SDM-7 menguasai bahasa sumber ilmu (arab dan inggris), indikator Manajemen-3 Training upgrading sharia, serta indikator Kinerja Manajerial 3 koordinasi. Hal ini ditunjukkan dari hasil wawancara, bahwa penerapan total quality management yang didasarkan pada tiga pilar, yaitu pengembangan kualitas SDM, sarana prasarana dan manajemen. Dari ketiga pilar tersebut peneliti menemukan hasilhasil yang realistis mengenai konsep penerapan total quality management pada Lembaga Keuangan Syariah di Kota Semarang.

2. Dari hasil pengujian analisis keterkaitan, bahwa hasil analisis peningkatan penguasaan manajemen syariah melalui penerapan total quality management menunjukan adanya hubungan yang signifikan terhadap kinerja manajerial. Terbukti dari pengujian signifikasi koefisien kontingensi (c) keterkaitan variabel total quality management pada kinerja manajerial. Secara lebih teknis, pengujian analisis keterkaitan tersebut dijelaskan sebagai berikut: 
a. Pada indikator Kualifikasi dan Standar SDM, terdapat 2 (dua) fungsi yang tidak mempunyai keterkaitan antara penguasaan manajemen syariah dengan kinerja manajerial BMT yaitu: fungsi dalam memahami konsep dan aplikasi transaksi (akad) serta fungsi dalam mengetahui dan memahami mekanisme kerja serta interaksi lembaga-lembaga terkait. Kedua fungsi tersebut memiliki probabilitas nilai $\chi^{2}$ yang tidak signifikan $(\phi>0,05)$. Namun, terdapat 5 (lima) fungsi yang memiliki keterkaitan antara penguasaan manajemen syariah dengan kinerja manajerial BMT. Fungsi yang memiliki keterkaitan tersebut, secara keseluruhan memiliki keeratan hubungan keterkaitan penguasaan manajemen syariah melalui penerapan TQM dengan kinerja manajerial BMT yang sedang, dimana nilai koefisien kontingensi (c) masing-masing instrumen berkisar antara $0,40-0,59$.

b. Pada indikator Sistem Pengelolaan Manajemen, tidak terdapat fungsi yang tidak mempunyai keterkaitan antara penguasaan manajemen syariah dengan kinerja manajerial BMT. Semua fungsi dalam indikator ini mempunyai keterkaitan dengan kinerja manajerial, yang dibuktikan dengan nilai probabilitas nilai $\chi^{2}$ yang signifikan $(p<$ 0,05). Fungsi dalam indikator Sistem Pengelolaan Manajemen, ratarata memiliki keeratan hubungan keterkaitan penguasaan manajemen syariah melalui penerapan TQM dengan kinerja manajerial BMT yang sedang, dimana nilai koefisien kontingensi (c) masing-masing instrumen berkisar antara 0,40 - 0,59. Namun, terdapat satu fungsi yaitu fungsi dilaksanakannya forum secara rutin dengan stakeholder LKS yang mempunyai keeratan hubungan keterkaitan penguasaan manajemen syariah melalui penerapan TQM dengan kinerja manajerial BMT yang kuat, dengan nilai koefisien kontingensi (c) sebesar 0,602 (0,60 $\leq c \leq 0,79)$.

c. Pada indikator Kualifikasi dan Standar SDM, terdapat 2 (dua) fungsi yang tidak mempunyai keterkaitan antara penguasaan manajemen syariah dengan kinerja manajerial BMT yaitu: fungsi ketersediaan gedung yang layak bagi pengembangan SDM, serta fungsi tersedianya ruang tunggu dan fasilitas umum. Kedua fungsi tersebut memiliki probabilitas nilai $\chi^{2}$ yang tidak signifikan $(p>0,05)$. Namun, terdapat 4 (empat) fungsi yang memiliki keterkaitan antara penguasaan manajemen syariah dengan kinerja manajerial BMT. 
Fungsi yang memiliki keterkaitan tersebut, secara keseluruhan memiliki keeratan hubungan keterkaitan penguasaan manajemen syariah melalui penerapan TQM dengan kinerja manajerial BMT yang sedang, dimana nilai koefisien kontingensi (c) masing-masing instrumen berkisar antara 0,40-0,59. Bahkan, terdapat satu fungsi yaitu fungsi teknologi informasi (IT) lembaga yang sudah memenuhi standar pelayanan yang mempunyai keeratan hubungan keterkaitan penguasaan manajemen syariah melalui penerapan TQM dengan kinerja manajerial BMT yang kuat, dengan nilai koefisien kontingensi (c) sebesar $0,680(0,60 \leq c \leq 0,79)$.

d. Secara keseluruhan terdapat 4 (empat) fungsi yang tidak mempunyai keterkaitan antara penguasaan manajemen syariah melalui penerapan TQM dengan kinerja manajerial BMT, serta terdapat 13 (tiga belas) fungsi keterkaitan antara penguasaan manajemen syariah melalui penerapan TQM dengan kinerja manajerial BMT.

\section{DAFTAR PUSTAKA}

Antonio, M. (1999). Bank Syariah Suatu Pengenalan Umum. Jakarta: Kerjasama Bank Indonesia dan Tazkia Institute.

Badan Pusat Statistik. (2015). STATISTIK INDONESIA 2015. Jakarta.

Bartol, K., \& Martin, D. (1998). Management. New York: The McGraw-Hill Companies.

Crosby, P. (1995). Quality Is Still Free: Making Quality Certain in Uncertain Times (2nd edition ed.). New York: McGraw-Hill Companies.

Deming, W. (1981). Management of statistical techniques for quality and productivity.

Departemen Agama RI. (1993). Al-Qur'an dan Terjemahannya, Yayasan Penyelenggara Penerjemaban / Penafsiran Al-Qur'an. Surabaya: Surya Cipta Aksara.

Dessler, G. (2012). Human Resource Management (13th Edition ed.). New Jersey: Prentice Hall.

Feigenbaum, A. V. (1991). Total Qaulity Control. New York: McGraw-Hill.

Gaspersz, V. (2008). Total Quality Management . Jakarta: Gramedia Pustaka Utama.

Goetsch, D., \& Davis, S. (2010). Quality Management For Organizational Excellence (X ed.). New Jersey: Pearson Prentice Hall.

Gujarati, D. (2009). Basic Econometrics (5th Editions ed.). Singapore: McGraw Hill. 
Indriantoro, N., \& Supomo, B. (2001). Metodologi Penelitian Bisnis (Edisi Pertama, Cetakan Kedua ed.). Yogyakarta: BPFE.

Juran, J. (1999). The quality improvement process. New York: McGraw Hill Company.

Juran, J., \& Godfrey, A. (1998). Juran's quality handbook (Fifth Edition ed.). New York: McGraw-Hill Companies,Inc.

Musari, K. (2010). TQM pada Perbankan Syariah.

Othman, A., \& Owen, L. (2005). The Multi Dimensionality of Carter Model To Measure Customer Service Quality In Islamic Banking Industry: A Study in Kuwait Finance House. International Journal of Islamic Financial Services, 3(4), 2.

Otley, D. d. (1996). Auditor Time Budget Pressure Consequence and Antecedents. Accounting Auditing \& Accountability Journal, Vol. 9(No. 1), p. 31-58.

Otoritas Jasa Keuangan. (2016). Statisktik Perbankan Syariah. Jakarta.

Render, B., \& Heizer, J. (2004). Operations Management. New Jersey: Pearson Education Inc. Upper Saddle River.

Saleh, K. (2005). Quality in Islamic Banking Sectors Model and Framework, Case: Kuwait Finance House-Bahrain. Australian Organisation for Quality.

Sallis, E. (2002). Total Quality Management in Education (3rd Edition ed.). Routledge.

Sashkin, M., \& Kiser, K. J. (1992). Putting Total Quality Management to Work. San Francisco: Berrett-Koehler Publishers.

Simamora, H. (1995). Manajemen Sumber daya Manusia. Yogyakarta: STIE YKPN.

Stoner, J., \& Freeman, R. (1995). Management (International 2 Revised ed edition ed.). Prentice-Hall.

Sugian, S. (2006). Kamus Manajemen (Mutu). Jakarta: PT Gramedia Pustaka Utama.

Tunggal, A. (1993). Manajemen Mutu Terpadu Suatu Pengantar. Jakarta: Rineka Cipta.

Waller, J., Allen, D., \& Burns, A. (1993). The Quality Management Manual: how to write and develop a successful manual for quality management systems. London: Kogan Page.

Yusanto, \& Karebet. (2007). Menggagas Bisnis Islam. Jakarta: Gema Isnsani.

Zaidi, J. (2006). Syari'a Quality Rating. AAOIFI Annual Conference Islamic Banking and Finance, 4 - 12. 